\title{
Relative growth of freshwater prawn Macrobrachium brasiliense (Decapoda, Palaemonidae) and its implications for reproduction
}

\author{
Caio dos Santos Nogueira' (D), Marcela Silvano de Oliveira ${ }^{2}$ (D), \\ Giuliano Buzá Jacobucci² (1) \& Ariádine Cristine de Almeida ${ }^{2}$ (B)
}

\begin{abstract}
1. Laboratório de Biologia de Camarões Marinhos e de Água Doce, Faculdade de Ciências, Universidade Estadual Paulista "Júlio de Mesquita Filho", Av. Eng. Luís Edmundo Carrijo Coube, 14-01, 17033-360 Bauru, SP, Brasil. (caiosnogueira@hotmail.com)

2. Laboratório de Ecologia de Ecossistemas Aquáticos, Instituto de Biologia, Universidade Federal de Uberlândia, Av. Pará, 1720, $38400-902$ Uberlândia, MG, Brasil. (ariadinecalmeida@ufu.br; gbjacobucci@gmail.com)
\end{abstract}

Received 14 June 2018

Accepted 18 December 2018

Published 24 January 2019

DOI 10.1590/1678-4766e2019005

\begin{abstract}
The main objective of this study was to estimate the morphological sexual maturity of Macrobrachium brasiliense (Heller, 1862) and to analyze the relative growth of the species. During one year of sampling, from July 2012 to June 2013, 199 specimens were collected in a stream located in a Cerrado biome, in the Triângulo Mineiro region, state of Minas Gerais. Once identified and sexed, the length of the carapace, the length of the segments of the chelipeds (ischium, merus, carpus, propodus and dactyl) and width of the pleura were measured (mm). The maximum and mean sizes of the carapace length measured $20.5 \mathrm{~mm}$ (Mean: $9.6 \pm 4.2 \mathrm{~mm}$ ) and $20.1 \mathrm{~mm}$ (Mean: $7.7 \pm 3.4 \mathrm{~mm}$ ) for males and females, respectively. The propodus length for males, and the pleura width for females, were used for the classification of the specimens into juvenile and adult, using K-means analysis and discriminant analysis. The relative growth of the species was also evaluated through covariance analysis for all structures $(\mathrm{ANCOVA}, \alpha=0.05)$. In females, the growth of most structures occurred equally between juveniles and adults, with the exception of the merus and pleura structures. On the other hand, the growth of almost all structures of males differed between juveniles and adults. Only the carpus and the pleura growth were similar. We also estimated the size at onset of morphological sexual maturity at $8.64 \mathrm{~mm} \mathrm{CL}$ for males $\left(\mathrm{CL}_{50 \%} \mathrm{r}=1.71\right)$ and $8.03 \mathrm{~mm} \mathrm{CL}$ for females $\left(\mathrm{CL}_{50 \%} \mathrm{r}=0.07\right)$. Our results contribute to the understanding of some important questions related to the reproductive biology of M. brasiliense. We noted that males grow differently from females and become the largest individuals in the population, resulting in a sexual dimorphism. Such sexual dimorphism might promote the development of the temporary mating guarding behavior, a reproductive strategy very important for caridean shrimps.
\end{abstract}

KEYWORDS. Allometry, morphological sexual maturity, reproductive biology.

RESUMO. Crescimento relativo do camarão de água doce Macrobrachium brasiliense (Decapoda, Palaemonidae) e suas implicações na reprodução. O objetivo principal deste estudo foi estimar a maturidade sexual morfológica de Macrobrachium brasiliense (Heller, 1862) e analisar o crescimento relativo da espécie. Durante um ano de coleta, de julho de 2012 a junho de 2013, foram coletados 199 espécimes em um riacho localizado em um bioma de Cerrado, na região do Triângulo Mineiro. Uma vez identificados e sexados, procedeu-se as medições (mm) do comprimento da carapaça, comprimento dos artículos do segundo pereópode (ísquio, mero, carpo, própodo e dáctilo) e largura da pleura. Os tamanhos máximos e médios do comprimento da carapaça foram 20,5 (média: 9,6 4,2 mm) e 20,1 mm (média: 7,7 $\pm 3,4 \mathrm{~mm}$ ) em machos e fêmeas, respectivamente. O comprimento do própodo para machos, e a largura da pleura para fêmeas foram utilizados para a classificação dos individuos em juvenis e adultos, usando a análise de K-means e análises discriminantes. O crescimento relativo das espécies também foi avaliado através da análise de covariância para todas as estruturas (ANCOVA, $\alpha=0,05)$. Nas fêmeas, o crescimento da maioria das estruturas ocorreu igualmente entre juvenis e adultos, com exceção do mero e pleura. Por outro lado, o crescimento de quase todas as estruturas dos machos diferiu entre juvenis e adultos. Apenas o crescimento do carpo e da pleura foi semelhante. $\mathrm{O}$ tamanho no início da maturidade sexual morfológica foi estimado em 8,64 mm CL para machos (CL50\% r = 1,71) e 8,03 mm CL para fêmeas (CL50\% $\mathrm{r}=0,07)$. Os resultados obtidos contribuem para a compreensão de algumas questões importantes relacionadas à biologia reprodutiva de $M$. brasiliense. Foi possível notar que os machos apresentam um crescimento diferencial quando comparados às fêmeas e se tornam os maiores indivíduos da população, resultando em um dimorfismo sexual. Tal dimorfismo sexual pode promover o desenvolvimento do comportamento de guarda temporária de acasalamento, uma estratégia reprodutiva muito importante para alguns camarões carídeos.

PALAVRAS-CHAVE. Alometria; maturidade sexual morfológica; biologia reprodutiva.

There are approximately 655 described species of freshwater prawns that represent a quarter of all prawns belonging to the infraorder Caridea. This infraorder is composed by many families, especially Palaemonidae, which has the largest number of species in continental waters (SAmpaIO et al., 2009). Among the genera of Palaemonidae, Macrobrachium Spence Bate, 1868 presents 19 species in Brazil, besides the introduced species $M$. rosenbergii (De
Man, 1859) (Pileggi \& Mantelatto, 2012). Some species of Macrobrachium, as the native prawn M. amazonicum (Heller, 1862), are of great relevance because their income sources from the small-scale fishing and aquaculture (HoLthuIs, 1980; OdinetZ-COLlart \& Moreira, 1993), as well as food resources for various fish species in the natural environment, including those of commercial interest (HONDA, 1974). 
Macrobrachium brasiliense (Heller, 1862) has a wide geographic distribution, occurring exclusively in freshwater environments in South America, with records in Venezuela, Colombia, Guianas, Suriname, Brazil, Ecuador and Peru (Holthuis, 1980; Coelho \& Ramos-Porto, 1984). In Brazil, M. brasiliense is recorded in the states of Amapá, Pará, Amazonas, Maranhão, Bahia, Mato Grosso, Mato Grosso do Sul, Goiás, Minas Gerais, São Paulo and Paraná (GARcíaDávila \& Magalhães, 2003; Pileggi et al., 2013).

A morphological study was carried out with a population of M. brasiliense located in the state of São Paulo (Mantelatto \& Barbosa, 2005), in which confirmed the differentiation in the development of body structures between males and females according to the different allometric rates performed. Research on other species of Macrobrachium has also demonstrated the importance of such morphometric analyzes in order to compare populations from different localities, especially when the size classes are different among these populations (Mossolin \& Bueno, 2003; PantaleÃo et al., 2012).

During the crustaceans ontogeny, some structures of its body might show evident morphological variations (HARTNOLL, 1978). Therefore, studies on relative growth provide important information on the life cycle of these animals, mainly in relation to the attainment of morphological sexual maturity and the presence or absence of sexual dimorphism (HARTNOLL, 1978, 1982). Usually, the growth of some corporal structures may vary according to the sex. Females, for example, invest most of their energy in reproduction, while males may invest their energy in the chelipeds growth, which can be, indirectly, related to reproductive biology of a particular species (HARTNOLL, 1978, 1982, 2001; Moraes-Riodades \& VAlenti, 2002; Pescinelli et al., 2014, 2015; DaVANSo et al., 2016).

In the present study, the main objective was to provide the first information about some biological characteristics of a population of $M$. brasiliense, located in the state of Minas Gerais, as the size in the morphological sexual maturity of males and females and the patterns of growth between juveniles and adults. The results herein provided may contribute to comparative studies among the populations of the species throughout their geographic distribution, evidencing possible variations in population dynamics.

\section{MATERIALS AND METHODS}

Specimens of M. brasiliense were collected monthly, from July 2012 to June 2013, in the Água Limpa stream (1908'24'S, 48 22'44'"W), located in a Cerrado biome, around the Uberlândia city, state of Minas Gerais. Samples were carried out by two collectors using sieves (mesh 1.0 $\mathrm{mm}$ ). The sieves were dragged along the submerged substrate at depths of 15 to $150 \mathrm{~cm}$, over a period of 90 minutes in order to catch the specimens. The captured individuals were kept in ice storage containers during transport to the laboratory, where they were transferred to labeled pots containing $70 \%$ ethanol for posterior identification, sexing and measurement with the use of a stereomicroscope and a vernier caliper $(0.1 \mathrm{~mm})$.

For morphometric analysis, different body structures (Fig. 1) were measured in males and females. Initially, the Mann-Whitney test was carried out to investigate differences in length between the articles of the right and left second chelipeds. As no significant difference was obtained ( $p>0.05$ ), only the measurements of the right cheliped were used in the analysis of demographic categorization, relative growth and sexual maturity. For these analyzes between the biometric relations of cheliped articles only animals that had both chelipeds intact were used. For the analysis of the second abdominal pleura, all individuals collected were used, therefore, they had this structure intact. During the analysis, there was no exclusion of outliers.

After measurement, the individuals were classified into juvenile and adult according to the differential growth of body structures in relation to carapace length. For this, a non-hierarchical K-means clustering analysis was applied considering the morphometric relationships CLvsPPL and CLvsPW for males and females, respectively. These body parts were chosen because of their importance in reproduction. The width of second pleura is related to the function of holding the egg mass during incubation, while the second pair of chelipeds has an important behavioral function for adult males during courtship (MANTELATTO \& BARBOSA, 2005).

The relative growth analysis was based on the allometric equation $y=a x^{b}$. In the equation, the letter $y$ represents the dependent variables (PW, IL, ML CRP, PPL, DCL, PPH), the letter $x$ represent the independent variable (CL), the $\alpha$ represents intercept on axis $y$, and $b$ represents the coefficient of allometric growth, converted to the linear form by means of natural logarithmic transformation ( $\ln y=$ $\ln a+b \ln x)$ (HARTNOLL, 1978). Covariance and homogeneity analyzes $(\alpha=0.05)$ were used to test the similarity of slopes and intercepts of the equations for each growth phase in both sexes. Student's t-test $(\alpha=0.05)$ was used to evaluate the allometric coefficient of growth (ZAR, 2010). Finally, growth was characterized as allometric positive $(b>1)$, allometric negative $(b<1)$ or isometric $(b=1)$ (HuXLeY, 1950).

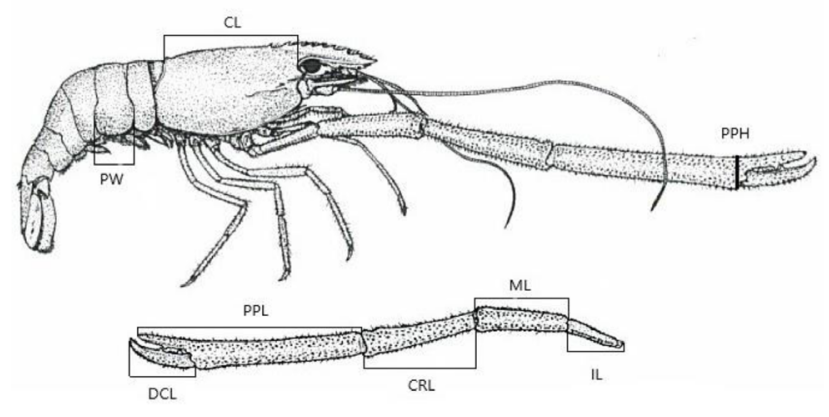

Fig. 1. Structures selected for morphometric analysis (CL, carapace length; PW, pleura width; IL, ischial length; ML, merus length; CRL, carpus length; PPL, propodus length; DCL, dactyl length; PPH, propodus height; measurements in mm). Adapted from Melo (2003). 
After categorization of the individuals into juveniles and adults, the size at onset of morphological sexual maturity in males and females was determined using the proportion of such demographic categories in size classes of $0.5 \mathrm{~mm}$ CL. The procedure used here was based on fitting the sigmoid logistic curve (e.g., Pinheiro \& Fransozo, 1998). We used the equation $y=1 /\left(1+e^{\left[-r\left(\mathrm{CL}-\mathrm{CL}_{50}\right)\right]}\right)$, where $y$ is the estimated proportion of adult shrimps, $C L$ is carapace length, $\mathrm{CL}_{50 \%}$ is the size at the onset of sexual maturity, and $r$ is the coefficient for the slope of the logistic curve. The logistic curve was fitted by least squares to the proportions per size class of all the individuals and samples using maximumlikelihood iterations. After adjusting the regression model, morphological sexual maturity $\left(\mathrm{CL}_{50 \%}\right)$ was estimated as the size at which $50 \%$ of the males and females reached maturity.

\section{RESULTS}

Relevant information was obtained about the reproductive biology of $M$. brasiliense in a Cerrado biome, in relation to the size at the onset of morphological sexual maturity, the relative growth between juveniles and adults and the sexual dimorphism.

A total of 198 individuals were analyzed, being 96 males, with CL ranging from 4.8 to $20.5 \mathrm{~mm}$, and 102 females, with CL ranging 4.8 to $20.1 \mathrm{~mm}$. From the results of the analysis of K-means, combined with the discriminant analysis, which were performed considering the pleura width (PW) and the propodus length (PPL), the individuals were classified into 53 juvenile males, 44 adult males, 75 juvenile females and 27 adult females.

Different equations were obtained for juvenile and adults males regarding almost all articles of the second pair of chelipeds (ANCOVA, $\mathrm{p}<0.01$, e.g. Fig. 2 , Tabs I, II). The morphometric relationships CLvsIL, CLvsML and CLvsCRL were characterized with isometric growth for juveniles, while the morphometric relationships CLvsPPL, CLvsPPH and CLvsDCL demonstrated negative allometric development for this same group, all the morphometric relationships related to the chelipeds were characterized by positive allometric development for adults, with the exception of the CLvsIL ratio, which was negative allometric (ANCOVA, $\mathrm{p}<0,05$ ). For the CLvsPW morphometric relation, negative allometry for juveniles and isometry for adults (ANCOVA, $p>0.05$, e.g. Fig. 2, Tab. I).

Considering the females, a difference in the growth pattern between juveniles and adults was observed for the morphometric relationships CLvsPW and CLvsPPH (ANCOVA, $\mathrm{p}<0.05$, e.g. Fig. 3 , Tabs I, II), in which a negative allometry was recorded for the juveniles and an isometry for

Tab. I. Regression analysis of morphometric data of Macrobrachium brasiliense (Heller, 1862). CL as an independent variable. *, significant difference. (CL, carapace length; PW, pleura width; IL, ischial length; ML, merus length; CRL, carpus length; PPL, propodus length; DCL, dactyl length; PPH, propodus height).

\begin{tabular}{|c|c|c|c|c|c|c|c|c|}
\hline Relation & Sex & $\mathrm{N}$ & $a$ & $b$ & $r^{2}$ & $t(H 0: b=1)$ & $p$ & Alometry \\
\hline \multirow{4}{*}{$\mathrm{PW} v s \mathrm{CL}$} & $\mathrm{AM}$ & 38 & -0.1915 & 0.757 & 0.84 & 0.16 & $<0.001 *$ & $=$ \\
\hline & $\mathrm{JM}$ & 58 & -0.2904 & 0.8507 & 0.74 & 2.24 & $<0.001 *$ & - \\
\hline & $\mathrm{AF}$ & 27 & -0.415 & 0.9793 & 0.86 & 0.26 & $<0.001 *$ & $=$ \\
\hline & $\mathrm{JF}$ & 75 & $-0,188$ & 0.7372 & 0.53 & 3.28 & $<0.001 *$ & - \\
\hline \multirow{4}{*}{ IL $v s \mathrm{CL}$} & $\mathrm{AM}$ & 32 & -0.2317 & 0.8001 & 0.70 & 2.13 & $<0.001 *$ & - \\
\hline & $\mathrm{JM}$ & 38 & -0.2636 & 0.7528 & 0.38 & 1.57 & $<0.001 *$ & $=$ \\
\hline & $\mathrm{AF}$ & 21 & -0.2697 & 0.8087 & 0.77 & 4.38 & 0.60 & - \\
\hline & $\mathrm{JF}$ & 55 & -0.2401 & 0.7312 & 0.26 & 9.69 & 0.78 & - \\
\hline \multirow{4}{*}{ ML vs CL } & $\mathrm{AM}$ & 32 & -0.6321 & 1.2641 & 0.91 & 3.71 & $<0.001 *$ & + \\
\hline & $\mathrm{JM}$ & 38 & $-0,2146$ & 0.7941 & 0.49 & 1.54 & $<0.001 *$ & $=$ \\
\hline & $\mathrm{AF}$ & 21 & -0.5339 & 1.1578 & 0.93 & 2.5 & 0.16 & - \\
\hline & $\mathrm{JF}$ & 55 & -0.2525 & 0.8263 & 0.39 & 10.11 & 0.47 & - \\
\hline \multirow{4}{*}{ CRL vs CL } & $\mathrm{AM}$ & 32 & -0.4899 & 1.1866 & 0.93 & 0.81 & $<0.001 *$ & + \\
\hline & $\mathrm{JM}$ & 38 & -0.2105 & 0.8625 & 0.41 & 3.23 & $<0.001 *$ & $=$ \\
\hline & $\mathrm{AF}$ & 21 & -0.4127 & 1.1057 & 0.91 & 2.51 & 0.12 & - \\
\hline & $\mathrm{JF}$ & 55 & -0.278 & 0.9451 & 0.48 & 9.65 & 0.46 & - \\
\hline \multirow{4}{*}{ PPL vs CL } & $\mathrm{AM}$ & 32 & -0.5588 & 1.4594 & 0.94 & 6.82 & $<0.001^{*}$ & + \\
\hline & $\mathrm{JM}$ & 38 & 0.0852 & 0.7546 & 0.45 & 1.76 & $<0.001 *$ & - \\
\hline & $\mathrm{AF}$ & 21 & -0.3426 & 1.2334 & 0.85 & 1.95 & 0.11 & - \\
\hline & $\mathrm{JF}$ & 55 & -0.062 & 0.942 & 0.52 & 9.67 & 0.17 & - \\
\hline \multirow{4}{*}{$\mathrm{DCL} v s \mathrm{CL}$} & $\mathrm{AM}$ & 32 & -0.9752 & 1.479 & 0.93 & 6.83 & $<0.001 *$ & + \\
\hline & $\mathrm{JM}$ & 38 & -0.2211 & 0.6836 & 0.36 & 2.1 & $<0.001 *$ & - \\
\hline & $\mathrm{AF}$ & 21 & -0.8655 & 1.3698 & 0.92 & 1.73 & 0.12 & - \\
\hline & $\mathrm{JF}$ & 55 & $-0,5941$ & 1.1322 & 0.51 & 9.01 & 0.95 & - \\
\hline \multirow{4}{*}{ PPH vs CL } & $\mathrm{AM}$ & 32 & -1.4376 & 1.4487 & 0.8 & 3.46 & $<0.001^{*}$ & + \\
\hline & $\mathrm{JM}$ & 38 & -0.671 & 0.6274 & 0.22 & 1.91 & $0.002 *$ & - \\
\hline & $\mathrm{AF}$ & 21 & -1.2338 & 1.2637 & 0.89 & 1.62 & 0.29 & $=$ \\
\hline & $\mathrm{JF}$ & 55 & -1.1791 & 1.2766 & 0.47 & 5.8 & $0.03 *$ & - \\
\hline
\end{tabular}



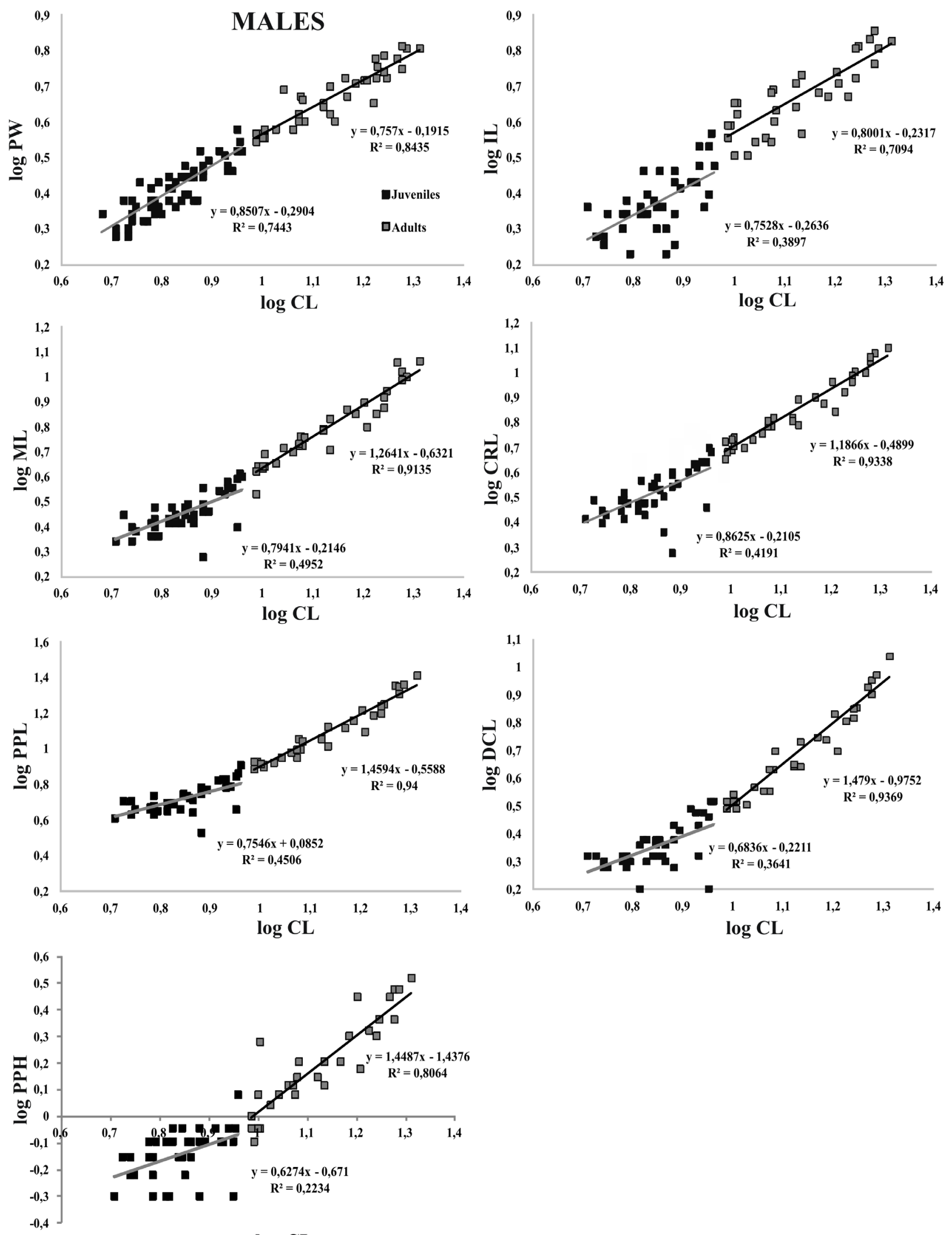

$\log \mathrm{CL}$

Fig. 2. Scatterplots of the morphometric relationships for males of Macrobrachium brasiliense (Heller, 1862) (CL, carapace length; PW, pleura width; IL, ischial length; ML, merus length; CRL, carpus length; PPL, propodus length; DCL, dactyl length; PPH, propodus height; measurements in mm). 

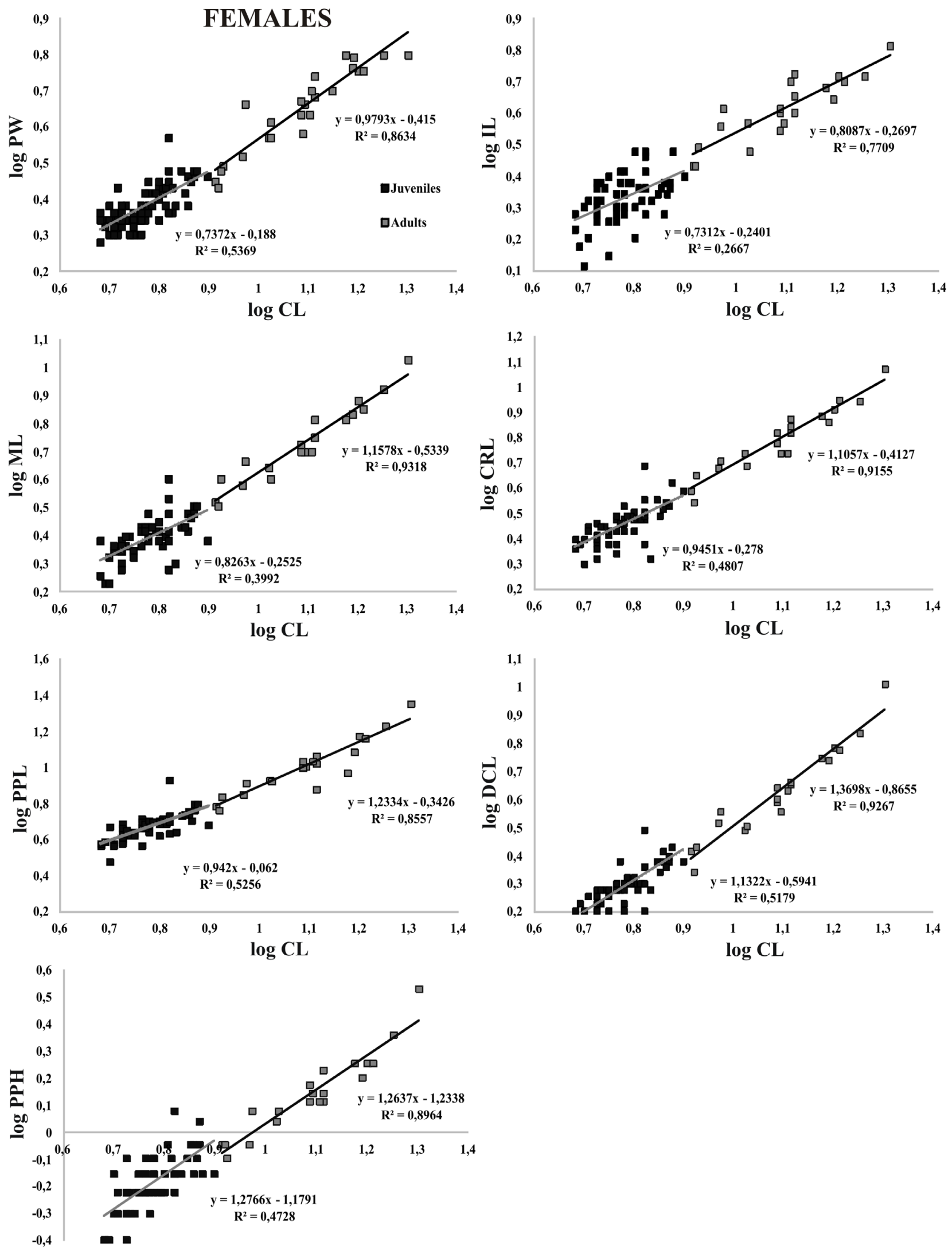

$\log \mathbf{C L}$

Fig. 3. Scatterplots of the morphometric relationships for females of Macrobrachium brasiliense (Heller, 1862) (CL, carapace length; PW, pleura width; IL, ischial length; ML, merus length; CRL, carpus length; PPL, propodus length; DCL, dactyl length; PPH, propodus height; measurements in mm). 
Tab. II. Results of covariance analysis (ANCOVA) of Macrobrachium brasiliense (Heller, 1862) (CL, carapace length; PW, pleura width; IL, ischial length; ML, merus length; CRL, carpus length; PPL, propodus length; DCL, dactyl length; PPH, propodus height).

\begin{tabular}{|c|c|c|c|c|}
\hline Relation & Group & Par. (log) & $\mathrm{F}$ & $\mathrm{p}$ \\
\hline \multirow{4}{*}{$\mathrm{PW}$ vs CL } & \multirow{2}{*}{ Male $\mathrm{J} v s \mathrm{~A}$} & $\mathrm{a}$ & 0.33 & 0.56 \\
\hline & & $\mathrm{b}$ & 1.17 & 0.28 \\
\hline & \multirow{2}{*}{ Female $\mathrm{J} v s \mathrm{~A}$} & $\mathrm{a}$ & - & - \\
\hline & & $\mathrm{b}$ & 4.85 & $0.02 *$ \\
\hline \multirow{4}{*}{ IL vs CL } & \multirow{2}{*}{ Male $\mathrm{J} v s \mathrm{~A}$} & $\mathrm{a}$ & 7.43 & $0.008 *$ \\
\hline & & $\mathrm{b}$ & 0.06 & 0.79 \\
\hline & \multirow{2}{*}{ Female $\mathrm{J} v s \mathrm{~A}$} & $\mathrm{a}$ & 1.35 & 0.24 \\
\hline & & $\mathrm{b}$ & 0.14 & 0.7 \\
\hline \multirow{4}{*}{ ML vs CL } & \multirow{2}{*}{ Male $\mathrm{J} v s \mathrm{~A}$} & $\mathrm{a}$ & - & - \\
\hline & & $\mathrm{b}$ & 10.27 & $0.002 *$ \\
\hline & \multirow{2}{*}{ Female $\mathrm{J} v s \mathrm{~A}$} & $\mathrm{a}$ & - & - \\
\hline & & $\mathrm{b}$ & 4.01 & $0.04 *$ \\
\hline \multirow{4}{*}{ CRL vs CL } & \multirow{2}{*}{ Male J vs A } & $\mathrm{a}$ & 0.93 & 0.33 \\
\hline & & $\mathrm{b}$ & 3.72 & 0.057 \\
\hline & \multirow{2}{*}{ Female $\mathrm{J} v s \mathrm{~A}$} & $\mathrm{a}$ & 0.13 & 0.71 \\
\hline & & $\mathrm{b}$ & 0.97 & 0.32 \\
\hline \multirow{4}{*}{ PPL $v s$ CL } & \multirow{2}{*}{ Male $\mathrm{J}$ vs A } & $\mathrm{a}$ & - & - \\
\hline & & $\mathrm{b}$ & 22.56 & $<0.001^{*}$ \\
\hline & \multirow{2}{*}{ Female $\mathrm{J} v s \mathrm{~A}$} & $\mathrm{a}$ & 0.34 & 0.55 \\
\hline & & $\mathrm{b}$ & 3.08 & 0.08 \\
\hline \multirow{4}{*}{ PPH vs CL } & \multirow{2}{*}{ Male $\mathrm{J} v s \mathrm{~A}$} & $\mathrm{a}$ & - & - \\
\hline & & $\mathrm{b}$ & 12.53 & $<0.001^{*}$ \\
\hline & \multirow{2}{*}{ Female $\mathrm{J}$ vs A } & $\mathrm{a}$ & 3.36 & 0.07 \\
\hline & & $\mathrm{b}$ & 0.00036 & 0.98 \\
\hline \multirow{4}{*}{$\mathrm{DL} v s \mathrm{CL}$} & \multirow{2}{*}{ Male $\mathrm{J} v s \mathrm{~A}$} & $\mathrm{a}$ & - & - \\
\hline & & $\mathrm{b}$ & 24.97 & $<0.001 *$ \\
\hline & \multirow{2}{*}{ Female $\mathrm{J} v s \mathrm{~A}$} & $\mathrm{a}$ & 3.23 & 0.07 \\
\hline & & $\mathrm{b}$ & 1.71 & 0.19 \\
\hline
\end{tabular}

adults in both cited relationships. The other relationships did not differ between the demographic category (ANCOVA, p $>0.05$, e.g. Fig. 3, Tab. I). For the CLvsIL, CLvsML, CLvsCRL, CLvsPPL and CLvsDCL relationships, negative allometric development was observed in both demographic categories (juvenile and adult) (ANCOVA, $\mathrm{p}>0.05$, e.g. Fig. 3 , Tab. I).

A sexual dimorphism considering the $\mathrm{CL}$ was recorded in the preset study (Mann-Whitney U test, $p<0.001$ ), with males reaching larger sizes $(9.64 \pm 4.17 \mathrm{~mm})$ when compared to the females $(7.7 \pm 3.39 \mathrm{~mm})$ of this population. The size at onset of morphological sexual maturity was estimated at $8.64 \mathrm{~mm}$ CL for males $\left(y=1 /\left(1+e^{[-1.71(\mathrm{CL}-8.64)]}\right)\right.$ and $8.03 \mathrm{~mm}$ CL for females $\left(y=1 /\left(1+e^{[-0.07(\mathrm{CL}-8.03)]}\right)\right.$.

\section{DISCUSSION}

According to HARTNOLL (2001), the growth of most crustaceans involves many moults, which preserve the morphological characteristics of the individuals but can suffer variations at the puberty moult. Some studies (MossoLIN \& Bueno, 2003; Mantelatto \& Barbosa, 2005; Paschoal et al., 2013) showed that the second pair of chelipeds and the second abdominal pleura are good indicators for the morphological sexual maturity of caridean prawns. Our findings also showed that the CLvsPPL and CLvsPW were the morphometric relationships that presented the best results for discriminating juveniles and adults in males and females of $M$. brasiliense, respectively.

Considering the above morphometric relationships (CLvsPPL and CLvsPW) it was recorded a negative allometry for both male and female juveniles. It is known that during the juvenile phase, the individuals direct their energy to somatic growth, aiming to achieve a sufficient body size for future reproductive success. Meanwhile, the adult individuals invest more energy for the development of the second pair of chelipeds and the second abdominal pleura, indicating that the first one is used by males in reproductive-related behaviors, and the second one is an important part of the incubator chamber of females (Mossolin \& BUENO, 2003; Mantelatto \& Barbosa, 2005; PAschoal et al., 2013).

For males of $M$. brasiliense, all articles of the chelipeds show differential growth when compared to juveniles, as observed for CLvsML, CLvsCRL CLvsPPL, CLvsDCL, CLvsPPH, all of which were positive and for CLvsIL, negative allometry. These results corroborate those by Mossolin \& Bueno (2003), which stated that the male chelipeds develops differently between the stages of life, becoming a great character for the definition of morphological sexual maturity. Correa \& THIEL (2003) argue that for some Caridea shrimp, which possess the mating system behavior, reproductive success is based on the size of body 
structures (such as chelipeds), it is larger for males than for females, since it is possible exclude their competitors and consequently monopolize several mating in a short period, resulting in the reproduction of success. In this way, the males of $M$. brasiliense can use its second pair of chelipeds in agnostic interactions, as proposed by CORREA \& THIEL (2003). However, for a concrete affirmation, courtship and mating experiments are necessary.

On the other hand, the relative growth of the female chelipeds was different for all the articles when compared to the males. These appendices might have distinct utilities between juveniles and adults of the population studied, as food search, territorial defense, agnostic behavior, courtship and mating behaviors (NAGAMINE \& KNIGHT, 1980; VOLPATO \& Hoshino, 1984; VAlenti et al., 1989; KARPlus et al., 1992; ISMAEL \& NEW, 2000). This result may reflect the usefulness of this appendage between both sexes; females may not need an appendage so developed for basic functions such as foraging and feeding, for example. However, studies are needed to confirm this assumption.

It was observed an isometric growth for adult females and negative allometry juvenile females considering the CLvsPW relationship. Therefore, in the adult phase of the females of $M$. brasiliense, the development of the second abdominal pleura accompanies in a same rhythm the development of the carapace. This result is corroborated by other study addressing population of this species that have a complete freshwater life cycle (MANTELATTO \& BARBOSA, 2005). Mantelatto \& Barbosa (2005) suggested that the probable reason for such result is related to the extremely fast egg incubation process. However, we believe in a synchronic growth between the CL and the PW since the longer the carapace length, the greater the space for the development of the ovaries. Consequently, there will be a greater production of oocytes that should have sufficient space in the abdominal cavity for incubation. Thus, both body structures must grow in similar proportions.

Considering the morphometric relationship CLvsPPL, it was possible to verify different allometric indexes between males and females. The males invested much more in the development of this structure which can influence the occurrence of sexual dimorphism in the species, once the chelipeds of the females may not reach large proportions. As mentioned before and based on the results, the juveniles of both sexes presented negative allometric development for almost all chelipeds morphometric relationships. Probably, these specimens do not invest much energy in the development of this appendage, because they also invest their energy in the growth of the carapace length in order to reach higher sizes to ensure reproductive success. When adults, the specimens direct their energy to the growth of other structures, such as the abdominal pleura and the propodus (CORREA \& ThIEL, 2003). In the study by MoraEs-Riodades \& VALENTI (2002), similar results were observed. Here, the allometric development of chelipeds was different among juveniles, males and females. Interestingly, the lowest allometric coefficient related to this body structure was obtained for juveniles, confirming that these specimens invested, initially, more energy in its somatic growth.

Conversely, the mean values of the carapace length of males and females, as well as the size at which they attained the onset of morphological sexual maturity, indicated a sexual dimorphism in M. brasiliense, which might be related to the "temporary mate guarding" sexual system, as proposed by BAUER (2004). According to the author, this system is observed for species that present intermediate population density, relatively aggressive males and sexual dimorphism in both body size and ornamentation of the second pair of chelipeds. Also, during the reproductive events, the male protects the female from potential predators and other males, keeping it until copulation. However, this behavior has a high cost for males, as a high energy investment for the growth of body and ornamentation of the cheliped, as well as the time and energy invested during the guarding of the female (BAUER, 2004). Similar results to the present study, with records of males larger than females, were obtained by GARCÍA-DÁvila et al. (2000), MANTELATTO \& BARBOSA (2005) and PEREIRA \& CHACUR (2009) for M. brasiliense, by FRANSOZO et al. (2004) for M. iheringi (Ortmann, 1897) and Mossolin \& BuENo (2003) for M. olfersii. All the authors related these results to the reproductive success of males, as well as to the differential growth of them in relation to females.

In general, the morphological variations observed between males and females of the distinct demographic categories of $M$. brasiliense in the present study contribute strongly to the understanding of the reproductive biology of the species. Based on the results obtained, it is possible that $M$. brasiliense presents the behavior of "temporary mate guarding", therefore, the body size of these animals would be directly related to the reproductive success of the larger individuals.

Acknowledgments. The authors are grateful to the FAPEMIG (Fundação de Amparo à Pesquisa de Minas Gerais) and to the Instituto de Biologia of the Universidade Federal de Uberlandia for providing financial support. We are thankful to our LEEA (Laboratório de Ecologia de Ecossistemas Aquáticos) coworkers for their help during the fieldwork. All sampling in this study has been conducted in compliance with current applicable state and federal laws.

\section{REFERENCES}

Bauer, T. B. 2004. Remarkable Shrimps: Adaptations and Natural History of the Carideans. Norman, University of Oklahoma Press. 282p.

Coelho, P. A. \& Ramos-Porto, M. 1984. Camarões de água doce do Brasil: distribuição geográfica. Revista Brasileira de Zoologia 2(6):405-410. DOI: $10.1590 / \mathrm{S} 0101-81751984000200014$

Correa, C. \& Thiel, M. 2003. Mating systems in caridean shrimp (Decapoda: Caridea) and their evolutionary consequences for sexual dimorphism and reproductive biology. Revista Chilena de Historia Natural 76(2):187-203. DOI: 10.4067/S0716078X2003000200006.

Davanso, T. M.; TAddei, F. G.; Hirose, G. L. \& Costa, R. C. 2016. Sexual maturity, handedness and sexual dimorphism of the freshwater crab Dilocarcinus pagei in south eastern Brazil. Boletim do Instituto de Pesca 42:269-279.

Fransozo, A.; Rodrigues, F. D.; Freire, F. A. M. \& Costa, R. C. 2004. Reproductive biology of the freshwater prawn Macrobrachium iheringi 
(Ortmann, 1897) (Decapoda: Caridea: Palaemonidae) in the Botucatu region, São Paulo, Brazil. Nauplius 12:119-126.

García-Dávila, C. R.; Alcantara, B. F.; Vásquez, R. E. \& Chujandama, S. M. 2000. Biologia reprodutiva do Camarão Macrobrachium brasiliense (Heller, 1862) (Crustacea: Decapoda: Palaemonidae) em Igarapés de terra firme da Amazônia Peruana. Acta Amazonica 30(4):653-664. DOI: $10.1590 / 1809-43922000304664$

García-DÁvila, C. R. \& Magalhães, C. 2003. Revisão taxonômica dos camarões de água doce (Crustacea: Decapoda: Palaemonidae, Sergestidae) da Amazônia Peruana. Acta Amazonica 33(4):663-686.

HARTNOLL, R. G. 1978. The determination of relative growth in Crustacea. Crustaceana 34(3):281-93.

Hartnoll, R. G. 1982. Growth. ln: Bliss, D. E. ed. The Biology of Crustacea. Embriology, Morphology and Genetics. New York, Academic Press, p. 111- 196.

HaRTNOLL, R. G. 2001. Growth in Crustacea - twenty years on. In: PAUlA, J. P. M.; Flores, A. A. V. \& Fransen, C. H. J. M. eds. Advances in decapod Crustacean research $-7^{\text {th }}$ Colloquium Crustacea Decapoda Mediterranea. Dordrecht, Kluwer Academic, p. 111-122.

Holthuis, L. B. 1980. Shrimps and prawns of the world: An annotated catalogue of species of interest to fisheries. FAO species catalogue. Fisheries Synopsis 125(1):1-271.

HoNDA, E. M. S. 1974. Contribuição ao conhecimento da biologia de peixes do Amazonas. II. Alimentação de tambaqui, Colossoma bidens (Spix). Acta Amazonica 4(2):47-53.

HuXLey, J. S. 1950. Relative growth and form transformation. Proceedings of the Royal Society of London 137(889):465-469.

Ismael, D. \& New, M. B. 2000. Biology. In: New, M. B. \& Valenti, W. C. Freshwater Prawn Culture: The Farming or Macrobrachium rosenbergii. London, Blackwell Science, p. 18-40.

Karplus, L.; Hulata, G.; Ovaoia, D. \& Affia, R. L. 1992. Social control of growth in Macrobrachium rosenbergii. IV. The role of claws in bull-runt interactions. Aquaculture 105(28): 1-296.

Mantelatto, F. L. M. \& Barbosa, L. R. 2005. Population structure and relative growth of freshwater prawn Macrobrachium brasiliense (Decapoda, Palaemonidae) from São Paulo State, Brazil. Acta Limnologica Brasiliensia 17(3):245-255.

Moraes-Riodades, P. \& VAlenti, W. C. 2002. Crescimento relativo do camarão canela Macrobrachium amazonicum (Heller) (Crustacea, Decapoda, Palaemonidae) em viveiros. Revista Brasileira de Zoologia 19(4):1181-1214.

Mossolin, E. C. \& Bueno, S. L. S. 2003. Relative growth of the second pereiopod in Macrobrachium olfersi (Wiegmann, 1836) (Decapoda, Palaemonidae). Crustaceana 76(3):363-376.

Nagamine, C. M. \& KNight, A. W. 1980. Development, maturation, and function of some sexually dimorphic structures of the Malaysian prawn, Macrobrachium rosenbergii (De Man) (Decapoda, Palaemonidae). Crustaceana 39(2):141-152.
Odinetz-Collart, O. \& Moreira, L. C. 1993. Potencial pesqueiro de Macrobrachium amazonicum na Amazônia Central (Ilha do Careiro): variação da abundância e do comprimento. Amazoniana 12:399-413.

Pantaleão, J. A. F.; Hirose, G. L. \& Costa, R. C. 2012. Relative growth, morphological sexual maturity, and size of Macrobrachium amazonicum (Heller 1862) (Crustacea, Decapoda, Palaemonidae) in a population with an entirely freshwater life cycle. Invertebrate Reproduction \& Development 56(3):180-190.

Paschoal, L. R.; Guimarães, F. J. \& Couto, E. C. 2013. Relative growth and sexual maturity of the freshwater shrimp Palaemon pandaliformis (Crustacea, Palaemonidae) in northeastern of Brazil (Canavieiras, Bahia). Iheringia, Série Zoologia 103(1):31-36.

Pereira, M. G. C. \& Chacur, M. M. 2009. Estrutura populacional de Macrobrachium brasiliense (Crustacea, Palaemonidae) do Córrego Escondido, Batayporã, Mato Grosso do Sul, Brasil. Revista de Biologia Neotropical 6(1):75-82.

Pescinelli, R. A.; Pantaleão, J. A. F.; Davanso, T. M. \& Costa, R. C. 2014. Relative growth and morphological sexual maturity of the freshwater crab Trichodactylus fluviatilis Latreille 1828 (Decapoda, Trichodactylidae) from west central São Paulo State, Brazil. Invertebrate Reproduction \& Development 58(2):108-114.

Pescinelli, R. A.; Davanso, T. M. \& Costa, R. C. 2015. Relative growth and morphological sexual maturity of the mangrove crab Aratus pisonii (H. Milne Edwards, 1837) (Decapoda, Brachyura, Sesarmidae) on the southern coast of the state of São Paulo, Brazil. Invertebrate Reproduction \& Development 59(2):55-60.

Pinheiro, M. A. A. \& Fransozo, A. 1998. Sexual maturity of the speckled swimming crab Arenaeus cribrarius (Lamarck, 1818) (Decapoda, Brachyura, Portunidae), in the Ubatuba littoral, São Paulo state, Brazil. Crustaceana 71(4):434-452.

PilegGi, L. G. \& Mantelatto, F. L. 2012. Taxonomic revision of doubtful Brazilian freshwater shrimp species of genus Macrobrachium (Decapoda, Palaemonidae). Iheringia, Série Zoologia 102(4):426-437.

Pileggi, L. G.; Magalhães, C.; Bond-Buckup, G. \& Mantelatto, F. L. 2013. New records and extension of the known distribution of some freshwater shrimps in Brazil. Revista Mexicana de Biodiversidad 84(2):563-574. DOI: 10.7550/rmb.30504

Sampaio, S. R.; Nagata, J. K.; Lopes, O. L. \& Masunari, S. 2009. Camarões de águas continentais (Crustacea, Caridea) da Bacia do Atlântico oriental paranaense, com chave de identificação tabular. Acta Biológica Paranaense 38:11-34.

Valenti, W. C.; Lobão, V. L. \& Mello, J. T. 1989. Crescimento relativo de Macrobrachium acanthurus (Wiegmann, 1836) (CRUSTACEA, DECAPODA, PALAEMONIDAE). Revista Brasileira de Zoologia 6(1):1-8.

Volpato, G. L. \& Hoshino, K. 1984. Adaptative process derived from the agonistic behavior in the freshwater prawn Macrobrachium iheringi (Ortmann, 1897). BoIetim de Fisiologia Animal 8:157-163.

ZAR, J. H. 2010. Biostatistical Analysis. New Jersey, Prentice-Hall. 994p. 